\title{
FACTORS INFLUENCING SOIL BEHAVIOR AND PROPERTIES OF MASS MOVEMENTS IN THE BLIMBING AREA, BRUNO DISTRICT, PURWOREJO REGENCY, CENTRAL JAVA, INDONESIA
}

\author{
Sari Bahagiarti KUSUMAYUDHA ${ }^{1}$ "DiD, Riskhy JUMADIL AKHIR ${ }^{1}$ and PURWANTO ${ }^{1}$
}

DOI: 10.21163/GT_2022.171.03

\begin{abstract}
:
The Blimbing area, Bruno district of Purwrejo Regency, Central Java, belongs to a susceptible area for mass movement. Its geomorphology expresses homoclinic hills, undulating plains, and denudated volcanic hills. The lithology is composed of sandstone of the Halang Formation and andesite breccia of the Peniron Formation. A study was conducted that aimed to examine the factors influencing soil behavior and mass movements in this area by applying an analytical descriptive method along with a field survey and surface mapping. There were eight slopes, namely Slope 1 to Slope 8, being examined and analysed. Slope 1 and Slope 5 are composed of high-plastic clay with very expansive properties. Slope 2 is occupied by high-plastic silt with slightly expansive properties. Slope 3 , Slope 4 , Slope 6 , and Slope 7 comprise high-plastic silt with slightly expansive to very expansive properties, while Slope 8 is built of highly fractured rock, with a joint density of $0.36 \mathrm{~m}$. Using the simplified Bishop method, it can be determined that Slope 1 to Slope 7 have safety factor values of $1.095,1.369,1.262,1.128$, $1.605,1.095$, and 0.961 , respectively. Slope 8 has a rock mass rating (RMR) value of 38 , which belongs to class IV (poor rock). It has the potential for wedge and toppling failures. Results of this study indicate that the existence of water in the slopes increases the load on the slopes by $15 \%$, decreasing the cohesion force and reducing the friction angle values, especially when the water content is more than $70 \%$. The type of soil is in the form of high-plastic clay and high-plastic silt that is slightly expansive to very expansive, with low permeability. Thus, water content and the very expansive soil are the main influencing factors for mass movements in the study area.
\end{abstract}

Key-words: Soil behaviour, Expansive clay, Poor rock, Water content, Mass movement.

\section{INTRODUCTION}

Soil/rock mass movements often occur in the Blimbing area and its surroundings in Bruno District, Purworejo Regency, Central Java, especially during the rainy season. The last landslide, which occurred in Tegalsari Village, resulted in 2 houses collapsing, 1 mosque, and 11 other houses threatened to move, with a total loss of more than 100 million rupiahs (BPS, 2021, Imam, 2021). The second rank of the landslide-prone areas in the Central Java province is the Purworejo Regency. It has an Indonesia Disaster Risk Index (IRBI) of $18^{\text {th }}$ out of 496 regencies and cities in Indonesia that are classified into a high-risk category (Wicaksono, 2020, BPS, 2021).

The study area belongs to an area with an average heavy rainfall of more than $2000 \mathrm{~mm} / \mathrm{year}$ (BMKG, 2021). Therefore, in order to identify and understand the factors influencing mass movement in the research area, it is necessary to study its soil behavior and characteristics so that the occurrence of mass movement can be anticipated, a countermeasure can be planned, and a mitigation model can be designed.

\footnotetext{
${ }^{1}$ Geological Engineering Department, Universitas Pembangunan Nasional Veteran Yogyakarta *Corresponding author: saribk@upnyk.ac.id; riskhyjumadil@upnyk.ac.id; purwanto_geotek@upnyk.ac.id
} 
The research location is administratively situated in the Bruno district, Purworejo regency, Central Java province. Astronomically, it is positioned at the coordinates of $\mathrm{X}=382000 \mathrm{mE}-388000 \mathrm{mE}$ and $\mathrm{Y}=91600000 \mathrm{mN}-9168000 \mathrm{mN}$ (Universal Transverse Mercator, World Geodetic System 1984 in zone 49S), (Fig. 1). This research aims to examine the factors that influence soil behavior of mass movements in the study area.

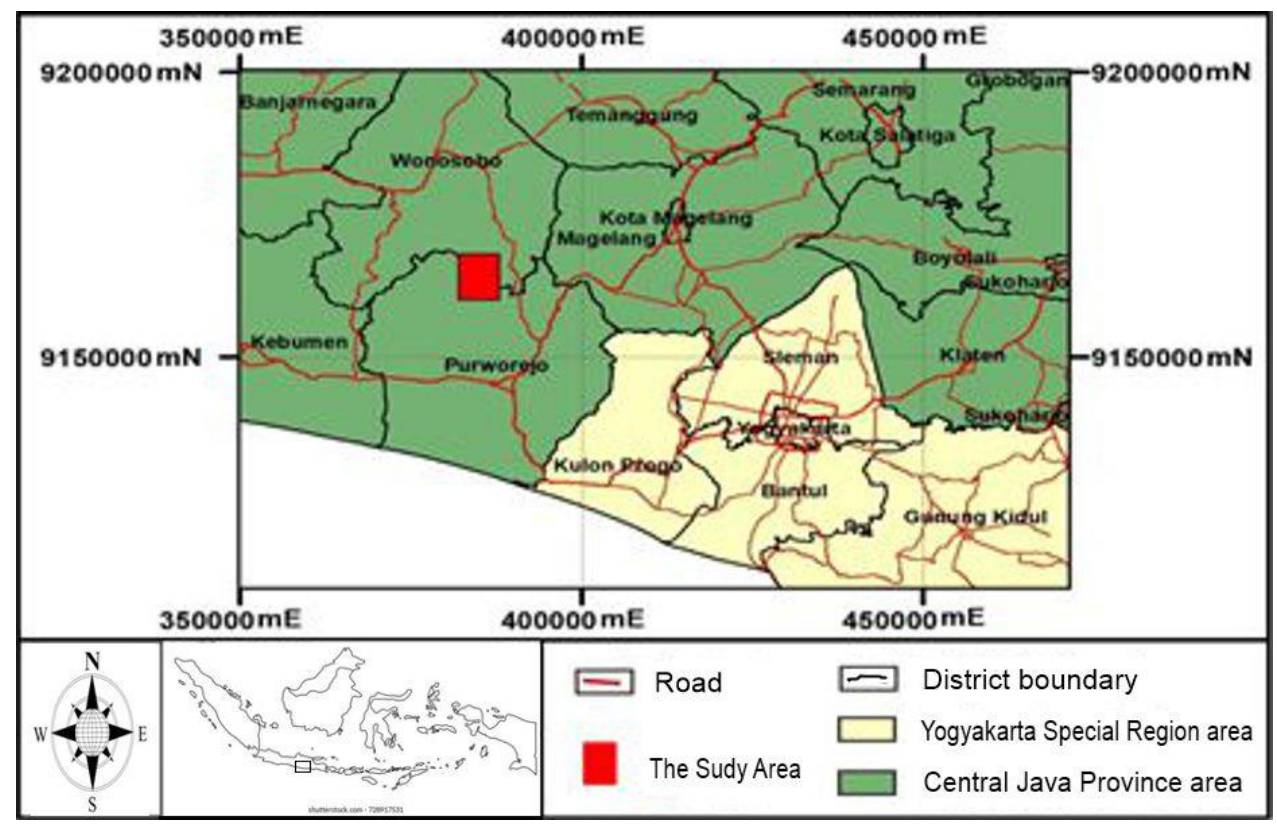

Fig. 1. Location map of the study area

(www.mapsofworld.com/indonesia/provinces/jawa-tengah.html).

\section{METHOD OF STUDY AND DATA}

This research applied an analytical-descriptive method with a field survey and surface mapping. Some undisturbed soil samples and rock samples were taken for laboratory testing and analysis. Sample testing and assessment in the laboratory included petrographic description; compressive strength tests for undisturbed soil samples, disturbed soil samples, rock samples, and unconfined compressive strength tests using the American Society for Testing and Material (ASTM D-2938-95) for rock mass rating (RMR). Determination of soil physical properties includes unit weight (ASTM D-2937), soil density (ASTM D-654-9), water content (ASTM D-2216-982), Atterberg limit (ASTM D-4318-89), permeability measurement (ASTM D-2434), soil shear strength analysis (ASTM D3080-72), and sieve analysis (ASTM C-136-06) for classifying the soil types.

The Simplified Bishop method was used in determining the safety factor of the slope formed by soil, with the assumption that the sliding plane is circular in form and the movement is rotational (Kusumayudha \& Ciptahening, 2016, Kusumayudha, et. al., 2020). In order to determine the type of soil mass movement, Varnes classification is used (Varnes, 1978). The RMR (rock mass rating) method is used to analyse slopes composed of rocks (Bieniawski, 1989), as well as the Markland Method (Citrabhuwana et al., 2016). The Simplified Bishop Method uses Limit Equilibrium and utilizes a sectional approach where the forces acting on each slice are shown as in Fig. 2 (Rajagukguk et al., 2014). In the RMR assessment, Table 1 and Table 2 were used (Bieniawki, 1989). 


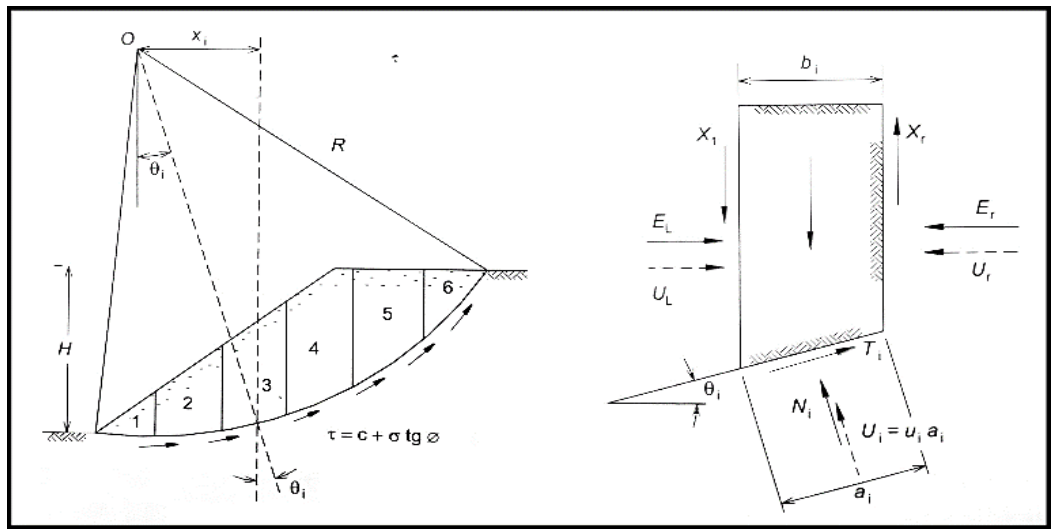

Fig. 2. Stress distribution in sliced soil slope (Rajagukguk, et.al., 2014).

Table 1.

Parameters and range of values of Rock Mass Rating (RMR), (Bieniawski, 1989).

\begin{tabular}{|c|c|c|c|c|c|c|c|c|}
\hline \multirow{3}{*}{$\begin{array}{l}\text { Parameter } \\
\text { Compressive } \\
\text { strength } \\
(\mathrm{Mpa})\end{array}$} & \multicolumn{8}{|c|}{ Range of Values } \\
\hline & Values & $>250$ & $100-250$ & $50-100$ & $25-50$ & $10-25$ & $3-10$ & $<3$ \\
\hline & Rating & 15 & 12 & 7 & 4 & 2 & & 0 \\
\hline \multirow[t]{2}{*}{ RQD (\%) } & Values & $90-100$ & $75-90$ & $50-75$ & $25-50$ & $<25$ & & \\
\hline & Rating & 20 & 17 & 13 & 8 & 3 & & \\
\hline Joint & Values & $>2$ & $0.6-2$ & $0.2-0.6$ & $0.06-0.2$ & $<0.006$ & & \\
\hline Dencity & Rating & 20 & 15 & 10 & 8 & 5 & & \\
\hline \multirow{8}{*}{$\begin{array}{l}\text { Joint } \\
\text { Condition }\end{array}$} & Values & Very rough & Slightly & Slightly & Slickensided & Soft gough $>5$ & & \\
\hline & & surfaces & rough & rough & surfaces or & $\mathrm{mm}$ thick, or & & \\
\hline & & & surfaces & surfaces & Gouge $<5$ & Separation > & & \\
\hline & & continuous & Separation & Separation $<1$ & $\mathrm{~mm}$ thick, or & $5 \mathrm{~mm}$ & & \\
\hline & & & $<1 \mathrm{~mm}$ & $\mathrm{~mm}$ & Separation 1 & Continuous & & \\
\hline & & separation & Slightly & Highly & $-5 \mathrm{~mm}$ & & & \\
\hline & & $\begin{array}{l}\text { Unweathered } \\
\text { wall rock }\end{array}$ & $\begin{array}{l}\text { weathered } \\
\text { walls }\end{array}$ & $\begin{array}{l}\text { weathered } \\
\text { walls }\end{array}$ & Continuous & & & \\
\hline & Rating & 30 & 25 & 20 & 10 & 0 & & \\
\hline $\begin{array}{l}\text { Ground- } \\
\text { water }\end{array}$ & Values & $\begin{array}{l}\text { Completely } \\
\text { dry }\end{array}$ & Damp & Wet & Dripping & Flowing & & \\
\hline Condition & Rating & 15 & 10 & 7 & 4 & 0 & & \\
\hline
\end{tabular}

In determining the plasticity index (PI) of soil, the interpretation of the plastic and liquid limits is carried out using the Casagrande diagram (Fig. 3). To classify the soil type, it uses the American Association of State Highway and Transportation Officials (AASHTO) naming system (Hardiyatmo, 2014). Expansive properties, expansive soils, and swelling potentials are used to indicate soils that are prone to shrinkage and contain a lot of clay, especially the mineral of montmorillonite (Hardiyatmo, 2014). Based on their expansive properties, there are three groups of clay minerals (Nelson \& Miller, 1991), namely kaolinite, non-expansive, mica-like, for example, illite and vermiculite, which can be expansive, and mildly developed illite, the smactite group, including montmotillonite, which is highly expandable or expansive (Duncan \& Fasce, 1995).

Table 2 .

Geomechanical classification of rock masses (Bieniawski, 1989).

\begin{tabular}{ccc}
\hline Class & Description of Rock Mass & RMR (Sum of Rating Increments) \\
\hline I & Very Good Rock & $81-100$ \\
II & Good Rock & $61-80$ \\
III & Fair Rock & $41-60$ \\
IV & Poor Rock & $21-40$ \\
V & Very Poor Rock & $>20$ \\
\hline
\end{tabular}


The relationship between the degree of soil expansion and the plasticity index according to ASTM D-1883 is shown in Table 3. This table describes the association between the value of plasticity index, the degree of swelling of the soil when it contains water, and the percentage of its expansion. For example, if the plasticity index value of the soil is 0 to 10 , the soil will be categorized as unexpansive, because the percentage of expansion is less than $2 \%$. On the other hand, when the plasticity index value is greater than 20 , then the soil is said to be very expansive or highly swelled, with a percentage expansion of more than $4 \%$. Meanwhile, the relationship between the potency of clay expansion and the plasticity index (PI) is laid out in Table 4 (Chen (1975).

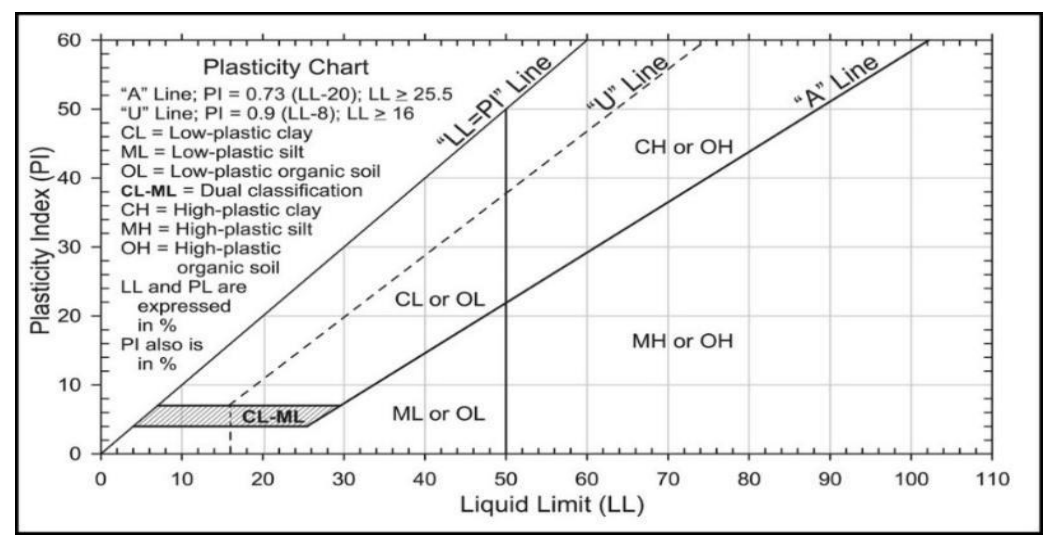

Fig. 3. Casagrande Diagram (ASTM D-2487).

Table 3.

Degree and \% of the expansive due to the plasticity index (PI) (ASTM D-1883, vide Hardiyatmo, 2014).

\begin{tabular}{ccc}
\hline $\begin{array}{c}\text { Plasticity Index } \\
\text { (ASTM D-424) }\end{array}$ & Degree of Expansive & $\begin{array}{c}\text { Percent of expansive } \\
\text { (ASTM D-1883) }\end{array}$ \\
\hline $0-10$ & Unexpansive & $2 \%$ or less \\
$10-20$ & Rather Expansive & $2 \%-4 \%$ \\
$>20$ & Very Expansive & $>4 \%$ \\
\hline
\end{tabular}

Table 4.

Relationship of the expansive potency and plasticity index (PI) (Chen, 1975).

\begin{tabular}{cc}
\hline Plasticity Index (PI) & Expansive Potency \\
\hline$>35$ & Very High \\
$20-55$ & High \\
$10-35$ & Moderate \\
$0-15$ & Low \\
\hline
\end{tabular}

\section{RESULTS AND DISCUSSIONS}

\subsection{Geomorphology and Geology}

The Blimbing and surrounding area are included in the South Serayu Mountains (Van Bemmelen, 1949), a geoanticlinic ridge stretching from the west to the east for $100 \mathrm{~km}$ (Fig. 4). Using Van Zuidam's classification (1984), the geomorphology of the study area can be divided into homoclinic hills, undulating plains, and denuded volcanic hills. The homoclinic hills are in the middle part, occupying $12.80 \%$ of the study area, with slopes of $7 \%-140 \%\left(4^{\circ}-55^{\circ}\right)$ very steep. The lowest elevation is $200 \mathrm{~m}$ asl and the highest is $500 \mathrm{~m}$ asl. The undulating plain occupies $63.05 \%$ of the study area, with slopes of $2 \%-140 \%\left(2^{\circ}-55^{\circ}\right)$, very sloping-very steep. The lowest elevation is $187 \mathrm{~m}$ asl, and the highest is $597 \mathrm{~m}$ asl. The denudated volcanic hills are located in the southeast, occupying $21.8 \%$ of the study area, with slopes of $15 \%-140 \%\left(8^{\circ}-55^{\circ}\right)$, moderate to very steep. 


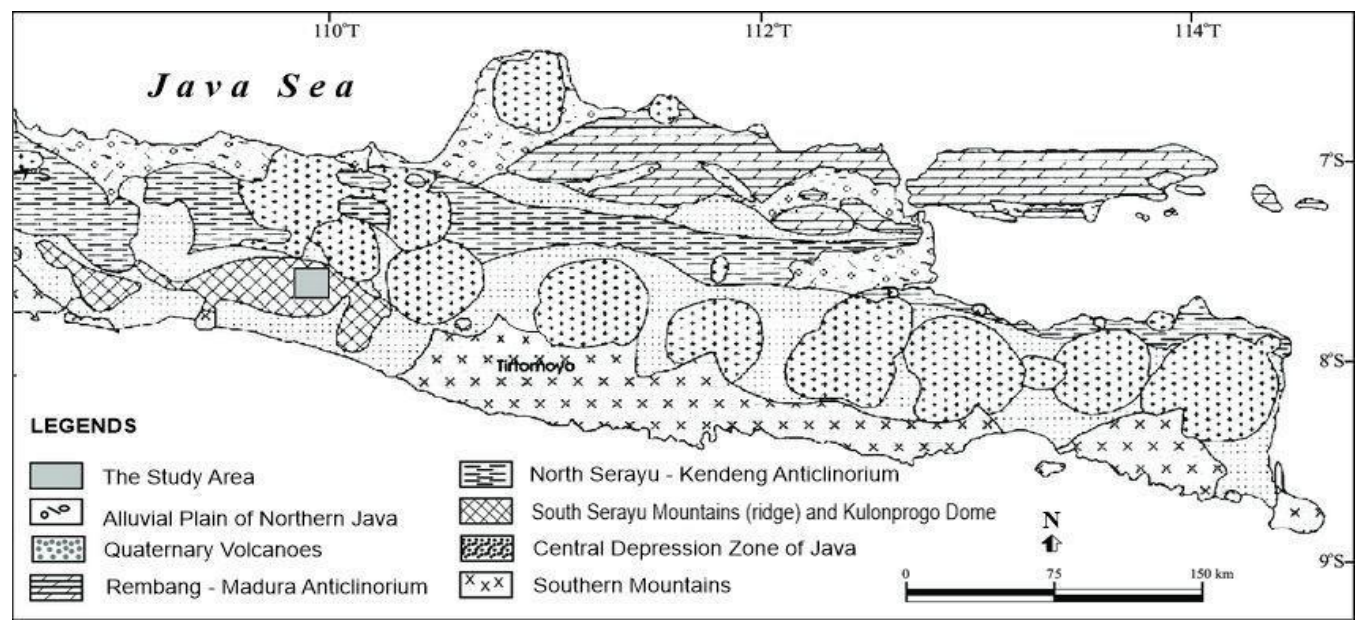

Fig. 4. The physiographic map of the Central - Eastern Java, and the study area belongs to the South Serayu Mountains (Van Bemmelen, 1949).

In the study area, there are two main rivers, namely Kali Jali and Kali Gowong, with relatively lateral erosion processes, so that the cross section of the rivers shows a "U" shape. Stratigraphically, the study area consists of alternating sandstones with claystones of the Halang Formation and volcanic andesite breccias of the Peniron Formation, in a conformable stratigraphical relationship (Fig. 5).

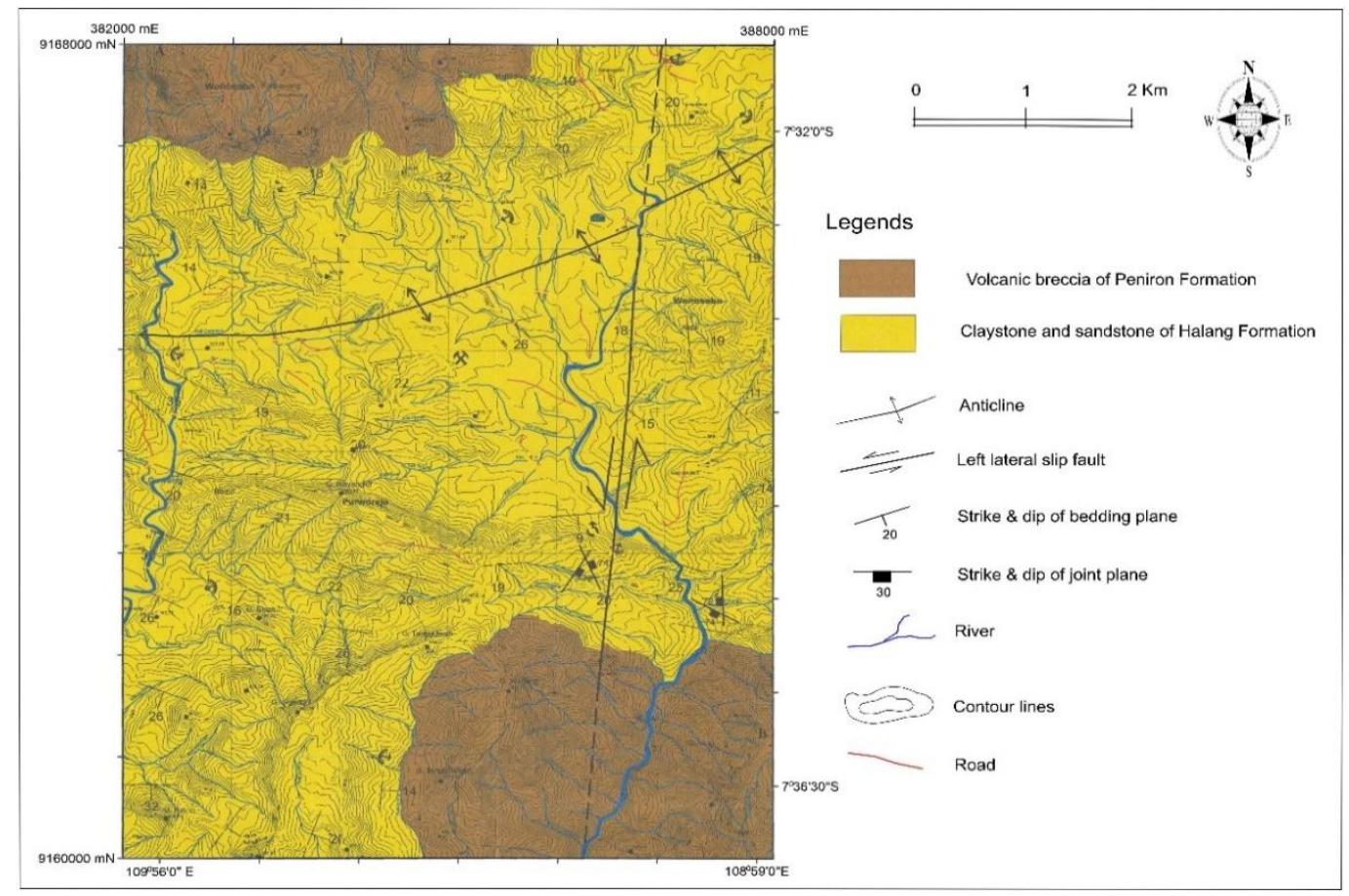

Fig. 5. Geological map of the study area.

The Halang Formation occupies $75.84 \%$ of the total study area, consisting of sandstone, claystone, carbonate sandstone, carbonate claystone, and polymixed breccia. The formation is late Miocene to early Pliocene epoch. The Peniron Formation consists of breccias with andesite fragments from the Pliocene epoch, which occupies the northwest and southeast areas of the study area. 
There is a normal left-slip fault in the study area called the Blimbing Fault (Fig. 5). The fault plane is striking $\mathrm{N} 6^{\circ} \mathrm{E}$ and dipping $70^{\circ}$, with a plunge of $5^{\circ}$, a bearing of $11^{\circ}$, and a rake of $32^{\circ}$. The general pattern of the shear joint is $\mathrm{N} 118^{\circ} \mathrm{E} / 72^{\circ}$ and $\mathrm{N} 173^{\circ} \mathrm{E} / 74$, while the distribution of principal stress is $1=0^{\circ}, \mathrm{N} 318^{\circ} \mathrm{E}, 2=70^{\circ}, \mathrm{N} 228^{\circ} \mathrm{E}$, and $3=19^{\circ}, \mathrm{N} 48^{\circ} \mathrm{E}$.

\subsection{Mass Movements}

Mass movements in the study area can mostly be classified as landslides. Although most of the mass movements in the study area involve weathered soil, in some locations the slopes are composed of rock, and they also often have the potential to fail. In this study, seven representative slopes comprising soil, coded as LR1, LR2, LR3, LR4, LR5, LR6, LR7 (Fig. 6 to Fig. 9), and one slope consisting of rock (LR8), were analysed. The selection of the studied slopes is based on their potential threat to settlements and/or public roads if they move.

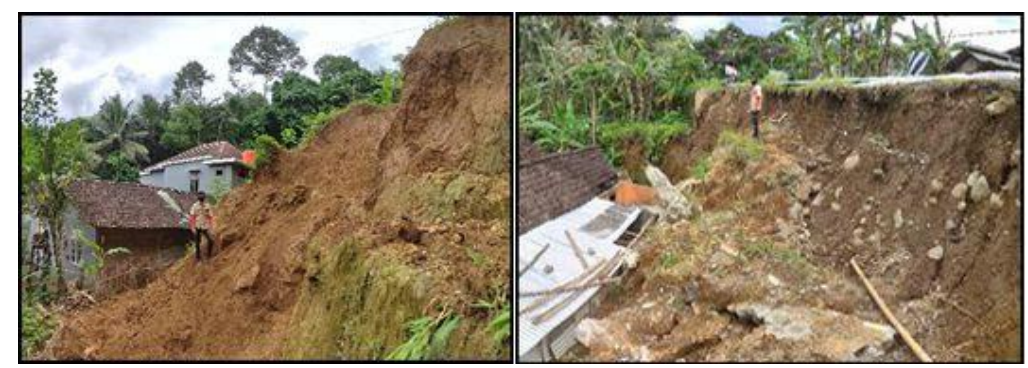

Fig. 6. Slope 1 (LR 1), left, and Slope 2 (LR 2), right.

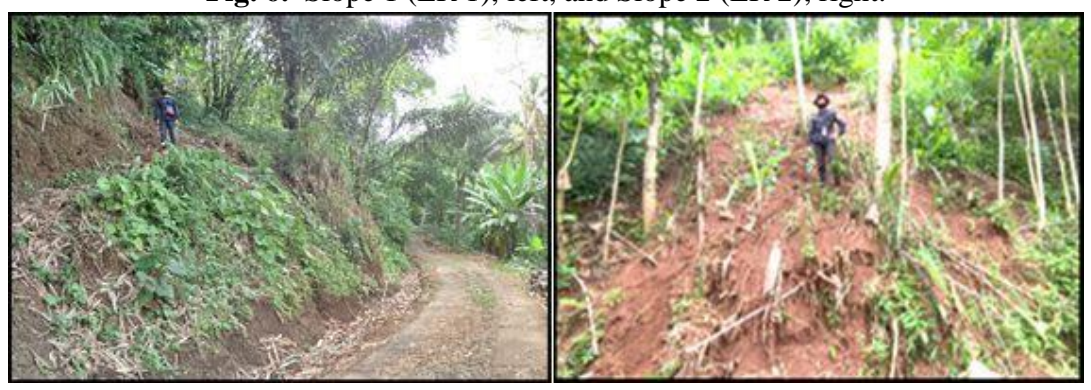

Fig. 7. Slope 3 (LR 3), left, and Slope 4 (LR 4), right.

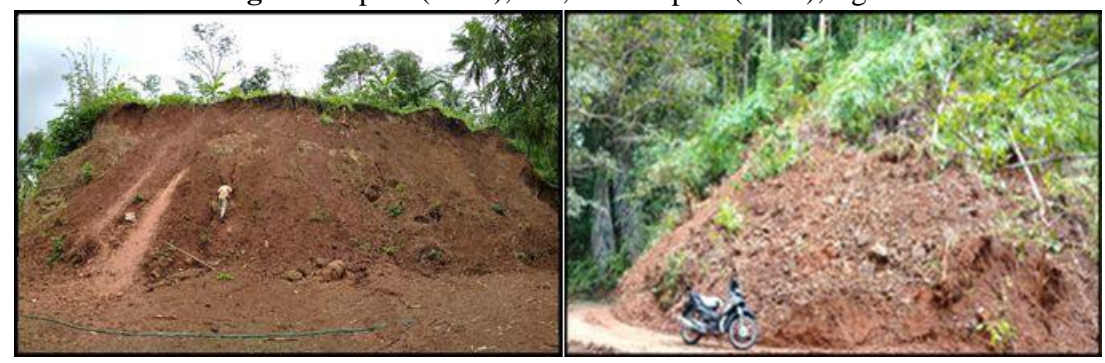

Fig. 8. Slope 5 (LR 5), left, and Slope 6 (LR 6), right.

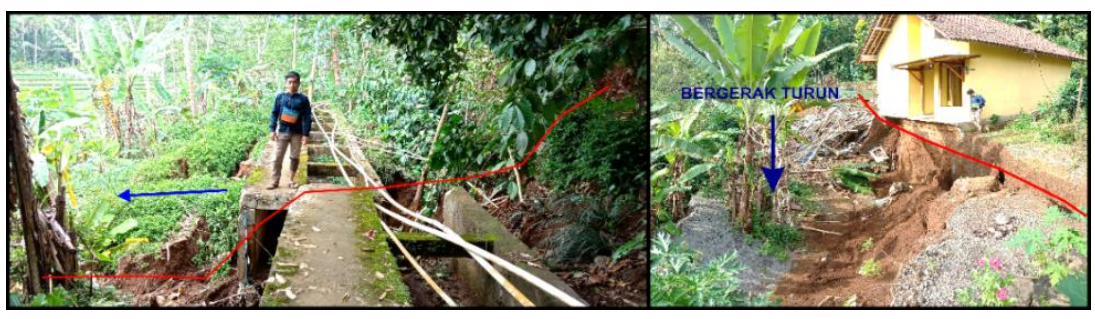

Fig. 9. Slope 7 (LR 7), and the direction of movement (blue arrow). 
Soil and rock samples for laboratory testing were also taken from those slopes. The results of soil physical properties testing are listed in Table $\mathbf{5}$.

Table 5.

Physical properties of the soil composing Slope 1 (LR1) to Slope 7 (LR7), and the rock of Slope 8 (LR8).

\begin{tabular}{|c|c|c|c|c|c|c|c|c|c|c|}
\hline \multirow[t]{2}{*}{ LR } & \multirow{2}{*}{$\begin{array}{l}\text { Unit } \\
\text { Weight } \\
(\mathrm{kg} / \mathrm{m} 3)\end{array}$} & \multirow{2}{*}{$\begin{array}{l}\text { Dry unit } \\
\text { Weight } \\
(\mathrm{kg} / \mathrm{m} 3)\end{array}$} & \multirow{2}{*}{$\begin{array}{l}\text { Specific } \\
\text { Gravity } \\
(\mathrm{gr} / \mathrm{cm} 3)\end{array}$} & \multirow{2}{*}{$\begin{array}{l}\text { Water } \\
\text { Content } \\
(\%)\end{array}$} & \multirow{2}{*}{$\begin{array}{l}\text { Permeability } \\
(\mathrm{cm} / \mathrm{s})\end{array}$} & \multicolumn{3}{|c|}{ Atterberg Limit } & \multicolumn{2}{|c|}{ Shear Strength } \\
\hline & & & & & & LL & $\mathrm{Pl}$ & PI & $\begin{array}{l}\mathrm{C} \\
(\mathrm{kN} / \mathrm{m} 2)\end{array}$ & $\Phi\left(^{\circ}\right)$ \\
\hline 1 & 1655.8 & 1113.1 & 2.43 & 46.35 & $5.5 \times 10-5$ & 59 & 30 & 29 & 25 & 20 \\
\hline 2 & 1301.5 & 663.45 & 2.21 & 822.04 & $7.63 \times 10-4$ & 57 & 48 & 9 & 21 & 25 \\
\hline 3 & 1552.54 & 1016.199 & 2.38 & 56.68 & $33.34 \times 10-4$ & 51 & 34 & 18 & 36 & 21 \\
\hline 4 & 2906.25 & 1666.14 & 2.34 & 80.47 & $5.85 \times 10-4$ & 67 & 44 & 23 & 8 & 49 \\
\hline 5 & 1637.5 & 1066.36 & 2.42 & 511.64 & $11.5 \times 10-4$ & 59 & 31 & 28 & 25 & 34 \\
\hline 6 & 1531.84 & 867.27 & 2.2 & 72.555 & $8.75 \times 10-4$ & 79 & 43 & 35 & 11 & 43 \\
\hline 7 & 1530.8 & 856.34 & 2.49 & 77.17 & $3.4 \times 10-4$ & 57 & 37 & 20 & 14 & 30 \\
\hline 8 & 0 & .23 & & & & & & & & \\
\hline
\end{tabular}

The results of the soil consistency test in the form of plasticity index (PI) and liquid limit (LL) values were then plotted into the Casagrande diagram for determining the soil type (Fig. 10).

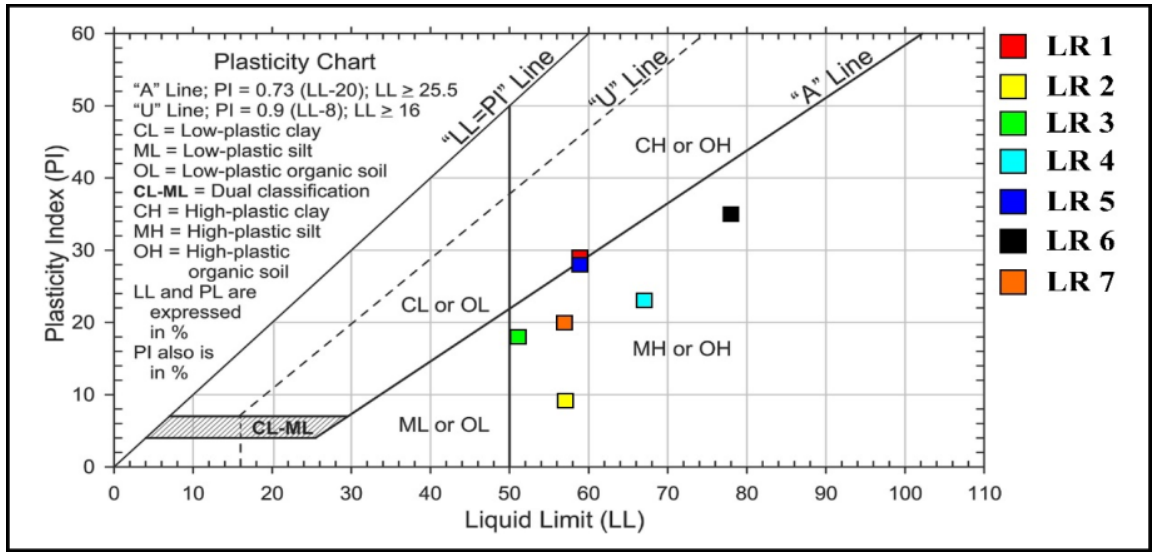

Fig. 10. The plots of liquid limit and plasticity index from LR1 to LR7 are used to determine the soil type. It shows that most of the soils are included in $\mathrm{MH}$ (high-plastic silt) or $\mathrm{OH}$ (high-plastic organic soil), except for LR1 and LR5, which belong to CH (high-plastic clay).

After being analysed, the soil samples taken from the representative slopes in the study area were classified using USCS and AASTHO classification as listed in Table 6.

Table 6.

Soil type (USCS and AASHTO classification) of mass movements in the study area.

\begin{tabular}{|c|c|c|c|c|c|c|c|}
\hline \multirow{2}{*}{$\begin{array}{l}\text { Slope } \\
\text { (LR) }\end{array}$} & \multicolumn{2}{|l|}{ USCS } & \multirow[t]{2}{*}{ AASTHO } & \multirow[t]{2}{*}{ PI } & \multirow{2}{*}{$\begin{array}{l}\text { Expansive } \\
\text { Degree }\end{array}$} & \multirow{2}{*}{$\begin{array}{l}\text { Expansive } \\
\text { Potential }\end{array}$} & \multirow{2}{*}{$\begin{array}{l}\text { Clay } \\
\text { Minerals }\end{array}$} \\
\hline & Symbol & Name & & & & & \\
\hline 1 & $\mathrm{CH}$ & $\begin{array}{l}\text { High-plastic } \\
\text { clay }\end{array}$ & A-7-5 (32) & 29 & Very Expansive & High & Smactite \\
\hline 2 & MH & High-plastic silt & A-5 (13) & 9 & Not Expansive & Low & Kaolinite \\
\hline 3 & MH & High-plastic silt & A-7-5 (19) & 18 & $\begin{array}{l}\text { Rather } \\
\text { Expansive }\end{array}$ & Medium & Mica-like \\
\hline 4 & MH & High-plastic silt & A-7-5 (30) & 23 & Very Expansive & High & Smactite \\
\hline 5 & $\mathrm{CH}$ & $\begin{array}{l}\text { High-plastic } \\
\text { clay }\end{array}$ & A-7-5 (32) & 28 & Very Expansive & High & Smactite \\
\hline 6 & MH & High-plastic silt & A-7-5 (44) & 35 & Very Expansive & Very high & Smactite \\
\hline 7 & MH & High-plastic silt & A-7-5 (22) & 20 & $\begin{array}{l}\text { Rather } \\
\text { Expansive }\end{array}$ & High & Mica-like \\
\hline
\end{tabular}


The expansive nature of soil depends on the type of clay content in it. By approaching ASTM (Chen, 1975; Nelson \& Miller, 1991) from the value of the plasticity index (PI), the expansive properties of soil can be known (Table 6). Table 6 shows that in all of the representative slopes being studied, the types of soil constituents are very expansive, having the potential to expand, and some of them contain smactite clay. This is reinforced by the results of petrographic analysis of the Halang tuffaceous sandstone unit, which shows the large content of volcanic material, especially plagioclase. It is known that when plagiolase undergoes weathering, clay minerals will be formed. On the 7 representative slopes, the determination of the safety factor was carried out using the simplified bishop method (Fig 11). The overall results are described in detail in Table 7.
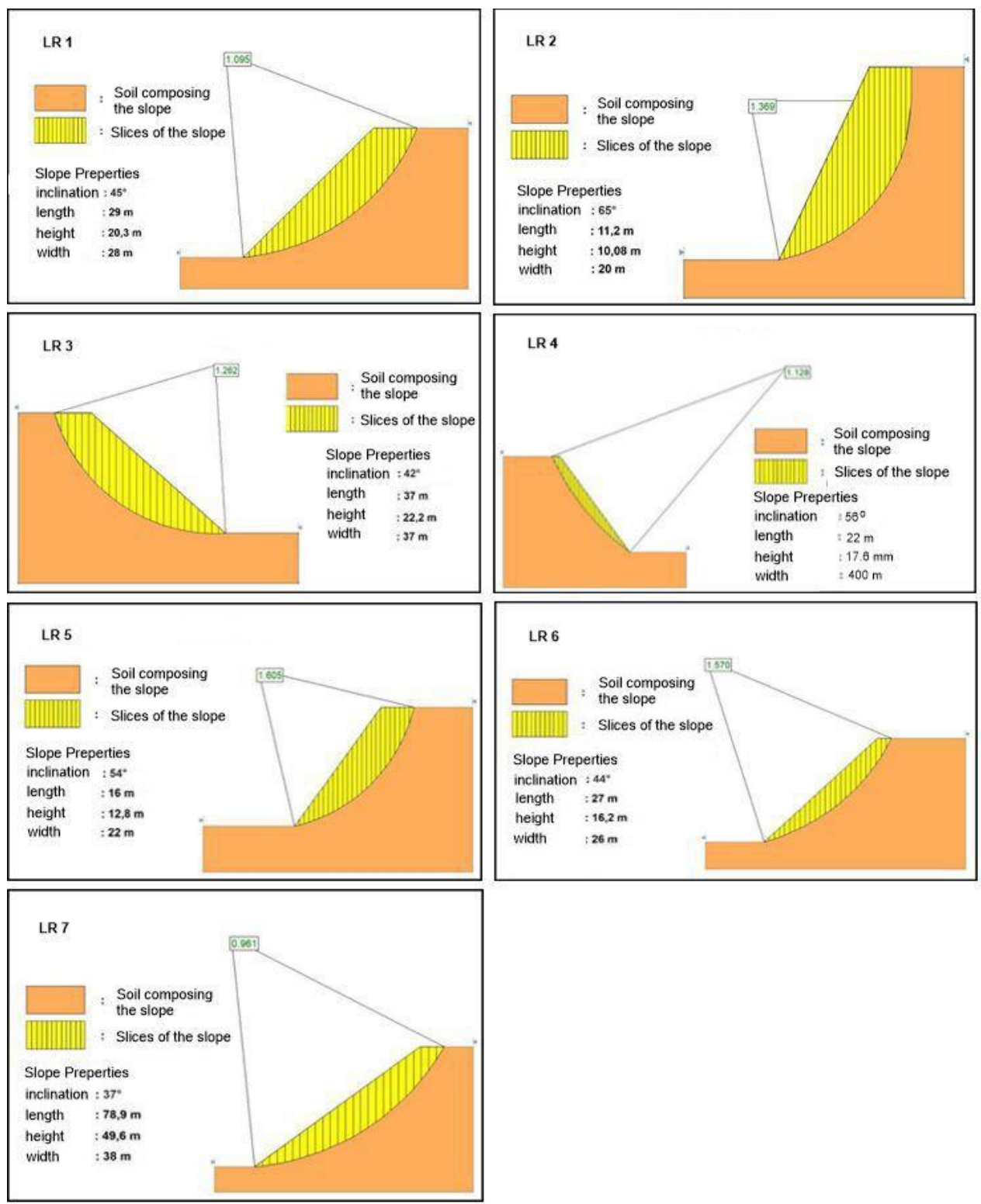

Fig. 11. Model of mass movements and factor of safety determination in the study area. 
Description of soil movements potential in the study area.

Table 7.

\begin{tabular}{|c|c|c|c|c|c|c|}
\hline $\begin{array}{l}\text { Slope } \\
\text { (LR) }\end{array}$ & Location & $\begin{array}{l}\text { Environment } \\
\text { and Slope } \\
\text { condition }\end{array}$ & Material & Soil properties & & $\begin{array}{l}\text { Safety Factor, } \\
\text { Movement } \\
\text { Type }\end{array}$ \\
\hline 1 & $\begin{array}{l}\text { Jangkrikan } \\
\text { village, } \\
387754 \mathrm{mE} \\
9167300 \mathrm{mN}\end{array}$ & $\begin{array}{l}\text { Farming area, } \\
\text { sloping } 45^{\circ} \text {, } \\
\text { slope length } \\
29 \mathrm{~m} \text {, }\end{array}$ & $\begin{array}{l}\text { Tuffaceous } \\
\text { sandstone of } \\
\text { Halang Fm, } \\
\text { intensively } \\
\text { weathered, } \\
\text { wet condition }\end{array}$ & $\begin{array}{l}\mathrm{CH} \text {, high } \\
\text { plasticity, } \\
\text { clay, A-7-5 } \\
(32), \\
\gamma=1301,5 \\
\mathrm{kN} / \mathrm{m} 3 \\
\text { Expansive } \\
\text { clay, smactite }\end{array}$ & $\begin{array}{l}\mathrm{C}=25 \\
\mathrm{kN} / \mathrm{m} 2 \\
\phi=20 \mathrm{o} \\
\mathrm{W}=46,35 \% \\
\mathrm{~K}=35 \mathrm{x} 10- \\
4 \mathrm{~cm} / \mathrm{s}\end{array}$ & $\begin{array}{l}\text { Fs }=1.095 \\
\text { Slump } \\
\text { (Landslide) } \\
\text { Slide } \\
\text { direction } \\
\text { N335oE }\end{array}$ \\
\hline 2 & $\begin{array}{l}\text { Jangkrikan } \\
\text { village, main } \\
\text { road side } \\
\text { Kutoarjo - } \\
\text { Bruno } \\
387049 \mathrm{mE} \\
9167841 \mathrm{mN}\end{array}$ & $\begin{array}{l}\text { Settlement } \\
\text { area, sloping } \\
45^{\circ}, \text { slope } \\
\text { length } 29 \mathrm{~m} \text {, }\end{array}$ & $\begin{array}{l}\text { Tuffaceous } \\
\text { sandstone of } \\
\text { Halang } \\
\text { Formation, } \\
\text { intensively } \\
\text { weathered, } \\
\text { wet condition }\end{array}$ & $\begin{array}{l}\text { MH, high } \\
\text { plasticity, silt, } \\
\text { A-5 (13), } \\
\gamma=1665,8 \\
\text { kN/m3 } \\
\text { Expansive } \\
\text { clay, smactite }\end{array}$ & $\begin{array}{l}\mathrm{C}=21 \\
\mathrm{kN} / \mathrm{m} 2 ; \phi= \\
25 \mathrm{o} \\
\mathrm{W}=82,04 \% \\
\mathrm{~K}=7.63 \mathrm{x} \\
10-4 \mathrm{~cm} / \mathrm{s}\end{array}$ & $\begin{array}{l}\text { Fs = 1.369 } \\
\text { Slump } \\
\text { (Landslide) } \\
\text { Slide } \\
\text { direction } \\
\text { N15oE }\end{array}$ \\
\hline 3 & $\begin{array}{l}\text { Kaliwungu } \\
\text { village, road } \\
\text { side of } \\
\text { Ngemplak - } \\
\text { Krawan, } \\
382508 \mathrm{mE} \\
9165122 \mathrm{mN}\end{array}$ & $\begin{array}{l}\text { Farming area, } \\
\text { fruit trees, } \\
\text { sloping } 42^{\circ} \text {, } \\
\text { slope length } \\
37 \mathrm{~m} \text {, }\end{array}$ & $\begin{array}{l}\text { Tuffaceous } \\
\text { sandstone of } \\
\text { Halang Fm, } \\
\text { intensively } \\
\text { weathered, } \\
\text { wet condition }\end{array}$ & $\begin{array}{l}\text { MH, high } \\
\text { plasticity, silt, } \\
\text { A-7-5 (13), } \\
\gamma=1552,54 \\
\text { kN/m3 } \\
\text { Expansive } \\
\text { clay, smactite }\end{array}$ & $\begin{array}{l}\mathrm{C}=35 \\
\mathrm{kN} / \mathrm{m} 2 ; \phi= \\
21 \mathrm{o} \\
\mathrm{W}=56,68 \% \\
\mathrm{~K}=3.34 \mathrm{x} \\
10-4 \mathrm{~cm} / \mathrm{s}\end{array}$ & $\begin{array}{l}\text { Fs = 1.262 } \\
\text { Slump } \\
\text { (Landslide) } \\
\text { Slide } \\
\text { direction } \quad \mathrm{N} \\
\text { 110oE }\end{array}$ \\
\hline 4 & $\begin{array}{l}\text { Suati - } \\
\text { Sruwudadi } \\
\text { Tengah, road } \\
\text { side } \\
384576 \mathrm{mE} \\
9161165 \mathrm{mN}\end{array}$ & $\begin{array}{l}\text { Farming area, } \\
\text { sloping } 56^{\circ}, \\
\text { slope length } \\
22 \mathrm{~m} \text {, }\end{array}$ & $\begin{array}{l}\text { Tuffaceous } \\
\text { sandstone of } \\
\text { Halang Fm, } \\
\text { intensively } \\
\text { weathered, } \\
\text { wet condition }\end{array}$ & $\begin{array}{l}\text { MH, high } \\
\text { plasticity, silt, } \\
\text { A-7-5 (30), } \\
\gamma=2906,25 \\
\text { kN/m3 } \\
\text { Expansive } \\
\text { clay, smactite }\end{array}$ & $\begin{array}{l}\mathrm{C}=8 \\
\mathrm{kN} / \mathrm{m} 2 \\
\phi=49 \mathrm{o} \\
\mathrm{W}=46,35 \% \\
\mathrm{~K}=35 \mathrm{x} \quad 10- \\
4 \mathrm{~cm} / \mathrm{s}\end{array}$ & $\begin{array}{l}\text { Fs = 1.128 } \\
\text { Slump } \\
\text { (Landslide) } \\
\text { Slide } \\
\text { direction } \\
\text { N115oE }\end{array}$ \\
\hline 5 & $\begin{array}{l}\text { Brunosari } \\
\text { village, main } \\
\text { road side } \\
382813 \mathrm{mE} \\
9162569 \mathrm{mN}\end{array}$ & $\begin{array}{l}\text { Farming area, } \\
\text { sengon trees, } \\
\text { sloping } 54^{\circ}, \\
\text { slope length } \\
16 \mathrm{~m} \text {, }\end{array}$ & $\begin{array}{l}\text { Tuffaceous } \\
\text { sandstone, } \\
\text { Halang Fm, } \\
\text { weathered but } \\
\text { there is rock } \\
\text { debris, } \\
\text { moistured } \\
\text { condition }\end{array}$ & $\begin{array}{l}\text { CH, high } \\
\text { plasticity, } \\
\text { clay, A-7-5 } \\
(32), \\
\gamma=1637,5 \\
\mathrm{kN} / \mathrm{m} 3 \\
\text { Expansive } \\
\text { clay, smactite }\end{array}$ & $\begin{array}{l}\mathrm{C}=25 \\
\mathrm{kN} / \mathrm{m} 2 ; \\
\phi=34 \mathrm{o} \\
\mathrm{W}=51,64 \% \\
\mathrm{~K}=11.5 \mathrm{x} \\
10-4 \mathrm{~cm} / \mathrm{s}\end{array}$ & $\begin{array}{l}\text { Fs }=1.605 \\
\text { Slump } \\
\text { (Landslide) } \\
\text { Slide } \\
\text { direction }\end{array}$ \\
\hline 6 & $\begin{array}{l}\text { Kaliwungu } \\
\text { village, road } \\
\text { side } \\
382813 \mathrm{mE} \\
9162569 \mathrm{mN}\end{array}$ & $\begin{array}{l}\text { Farming area, } \\
\text { sloping } 45^{\circ} \text {, } \\
\text { slope length } \\
29 \mathrm{~m} \text {, }\end{array}$ & $\begin{array}{l}\text { Tuffaceous } \\
\text { sandstone of } \\
\text { Halang Fm, } \\
\text { intensively } \\
\text { weathered, } \\
\text { wet condition }\end{array}$ & $\begin{array}{l}\text { MH, high } \\
\text { plasticity. silt, } \\
\text { A-7-5 (32), } \gamma \\
=1665,8 \\
\mathrm{kN} / \mathrm{m} 3 \\
\text { Expansive } \\
\text { clay, smactite }\end{array}$ & $\begin{array}{l}\mathrm{C}=25 \\
\mathrm{kN} / \mathrm{m} 2 ; \phi= \\
20 \mathrm{o} \\
\mathrm{W}=51,64 \% \\
\mathrm{~K}=11,5 \quad \mathrm{x} \\
10-4 \mathrm{~cm} / \mathrm{s}\end{array}$ & $\begin{array}{l}\text { Fs }=1.570 \\
\text { Slump } \\
\text { (Landslide) } \\
\text { Slide } \\
\text { direction }\end{array}$ \\
\hline 7 & $\begin{array}{l}\text { Tegalsari } \\
\text { village, main } \\
\text { road side } \\
\text { Kutoarjo - } \\
\text { Bruno } \\
385599 \mathrm{mE} \\
9163143 \mathrm{mN}\end{array}$ & $\begin{array}{l}\text { Threatening } \\
12 \text { houses, } \\
\text { sloping } 37^{\circ} \text {, } \\
\text { slope length } \\
78.3 \mathrm{~m} \text {, }\end{array}$ & $\begin{array}{l}\text { Tuffaceous } \\
\text { sandstone of } \\
\text { Halang Fm, } \\
\text { intensively } \\
\text { weathered, } \\
\text { wet condition, }\end{array}$ & $\begin{array}{l}\text { MH, high } \\
\text { plasticity, silt, } \\
\text { A-7-5 (22), } \\
\gamma=1530,8 \\
\text { kN/m3 } \\
\text { Expansive } \\
\text { clay, illite }\end{array}$ & $\begin{array}{l}\mathrm{C}=14 \\
\mathrm{kN} / \mathrm{m} 2 ; \phi= \\
30 \mathrm{o} \\
\mathrm{W}=77.1 \% \\
\mathrm{~K}=3.4 \mathrm{x} \\
10-4 \mathrm{~cm} / \mathrm{s}\end{array}$ & $\begin{array}{l}\text { Fs }=0.961 \\
\text { Slump } \\
\text { (Landslide) } \\
\text { Slide } \\
\text { direction }\end{array}$ \\
\hline
\end{tabular}


The next example of the slope to be investigated is LR8. It is located beside the road connecting Blimbing village and Somoleter village and next to the Blimbing fault geological structure. On this slope, mass movement potential is in the direction of $\mathrm{N} 20^{\circ} \mathrm{E}$ and threatens the road body. Administratively, the slope belongs to Somoleterkrajan hamlet, Somoleter village. The UTM coordinates are $386564 \mathrm{mE}$ and $9163143 \mathrm{mN}$. The morphology at this location has a slope of $63^{\circ}$. In the unit composed of the Halang tuffaceous sandstone unit, the position of the groundwater table is not clearly found, but in the joint set of the rock, there are water drops. It indicates that the rock is saturated with water. The land use at this location is shrubs. This type of potential mass movement can be categorized as a rockslide. A rock mass rating has been carried out on this slope, and the results show that the rocks that make up the slope have a total score equal to 38. It means that the material composing the slope can be classified as poor rock. (Table 8).

Rock mass rating of slope 8 (LR 8).

\begin{tabular}{lll}
\hline Parameter & Assessment & Rating \\
\hline Rock Strength & $7.231 \mathrm{MPa}$ & 2 \\
RQD & $33.50 \%$ & 8 \\
Joint Spacing & $0.36 \mathrm{~m}$ & 10 \\
Joint Condition & Opening of $1-5 \mathrm{~mm}$ & 10 \\
Groundwater Condition & Wet and saturated & 7 \\
\hline \multicolumn{2}{c}{ Total Score / Class } & 38 / Poor Rock \\
\hline
\end{tabular}

There are discontinuity planes at this location with the strike and dip of joint set 1 (JS1) N203 ${ }^{\circ} \mathrm{E} / 82^{\circ}$, joint set $2(\mathrm{JS} 2) \mathrm{N} 226^{\circ} \mathrm{E} / 72^{\circ}$, joint set 3 (JS) $\mathrm{N} 80^{\circ} \mathrm{E} / 21^{\circ}$, the slope face is $\mathrm{N} 280^{\circ} \mathrm{E} / 63^{\circ}$, and the friction angle is $25^{\circ}$. The plot of this data for Markland analysis is shown in Fig. 12.

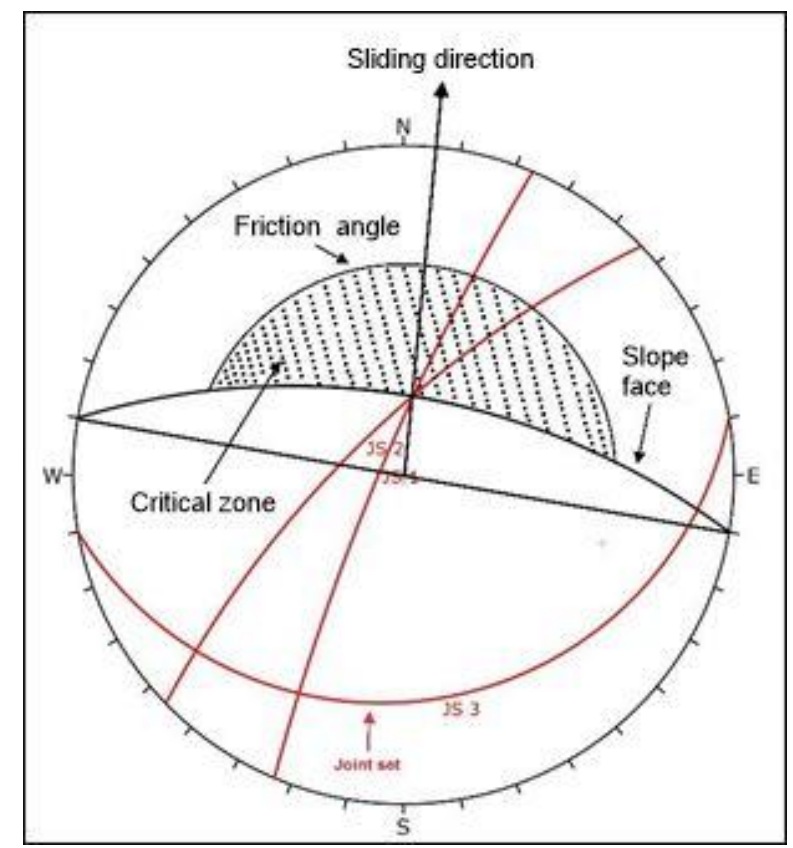

Fig. 12. The stereonet plot of LR 8, showing failure potencies of wedge type through the interception of JS2 and JS4, and toppling through JS 3.

The result of the stereonet plot and markland analysis demonstrate that the slope is not safe and the type of landslide potential is wedge and toppling failures. As well as the strike of the discontinuity plane, which is represented by the joint set of 3 forming an angle of $20^{\circ}$ toward the strike of the slope, so that it will form a toppling landslide. 


\subsection{Soil Behavior and Characteristics}

In this study, the formation that has the highest potential to be eroded is the Halang Formation, which consists of mainly clayey sandstone and claystone. Based on the results of laboratory analysis that showed the permeability values are very low, it can be inferred that the speed of water movement in the lithology composing the slopes being studied is very slow. This will trigger the existence of hydrostatic pressure in terms of pore pressure to weaken the shear strength of the slope (Kusumayudha, et al, 2020).

The soil cohesion (c) values of the investigated slopes range from $8 \mathrm{KN} / \mathrm{m} 2$ to $25 \mathrm{KN} / \mathrm{m} 2$, and the internal friction angle $(\square)$ values extent from $20^{\circ}$ to $49^{\circ}$. The types of soil are high plastic clay and high plastic silt with slightly expansive potential to very expansive, so that it will cause swelling when the water content is high and be able to form cracks if it loses its water content. The permeability ranges from $3.410^{-4}$ to $5.510^{-5}$ and the water content ranges from $46.35 \%$ to $80.47 \%$. This shows that the speed of water movement in the body of the slopes is very low. With this very slow motion, the presence of water in the soil will cause hydrostatic pressure in the pores of the material. In turn, this condition will increase the weight force, reduce the cohesion force (c) value, and reduce the friction angle ( $\square$ ) (Fig. 13, Fig. 14, Fig. 15), thereby increasing the potential for mass movements in the area.

On slopes made up of rocks, such as LR8, the uniaxial compressive strength value of the rock is $7,231 \mathrm{Mpa}$, indicating that this rock is very weak (Hoek \& Bray 1997). The result of the rock mass rating (RMR) on this slope is 38 , which is classified as poor rock in class IV. Of course, poor rock has a higher potential to fail. Based on the Markland method, the potential failure types are wedge and toppling.

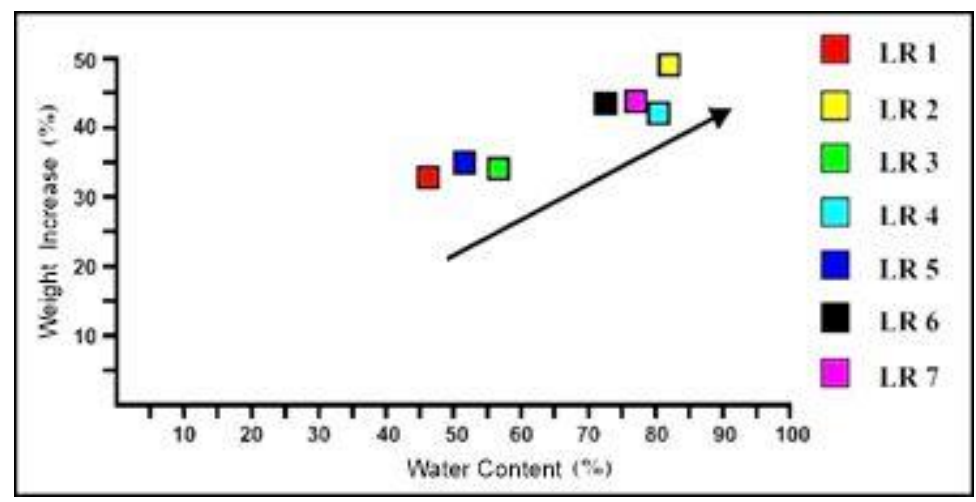

Fig. 13. The plots of water content and percent weight increase of the soil sample, showing the correlation of water content and weight increase. The higher the water content, the greater the percentage of the soil weight increase.

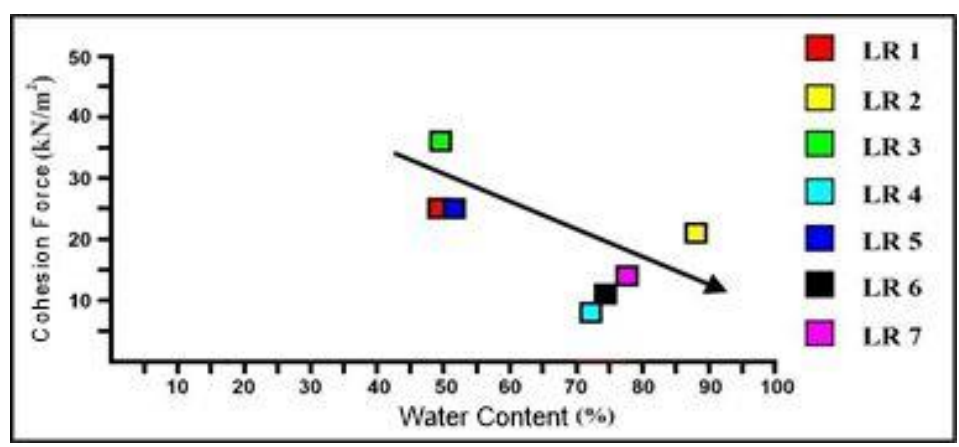

Fig. 14. The plots of water content and cohesion force value of the soil sample, showing the correlation of water content and cohesion force (c). The higher the water content, the lower the cohesion force. 


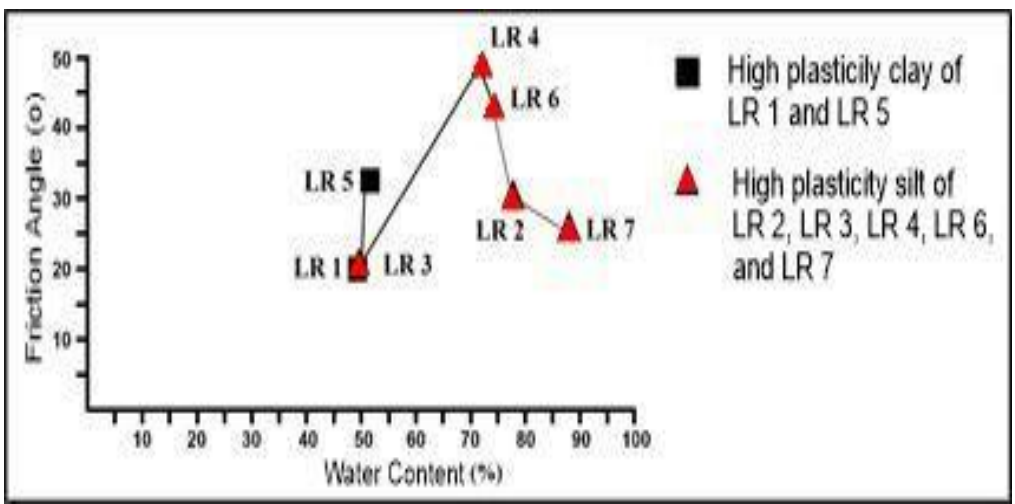

Fig. 15. The plots of water content and friction angle ( $\square)$ value of the soil sample, showing that when the water content is higher than $70 \%$, the friction angle will decrease.

The results of this study demonstrate that the factors influencing soil behavior in the occurrence of mass movement are the type of clay mineral (smactite group) and the amount of water content in the soil. Thus, the information on soil properties is very important to be understood by stakeholders in managing landslide-prone areas. Soil which is very expansive with high water content, low cohesion force, and low friction angle value will decrease its shear strength and therefore is susceptible to landslides. By knowing the soil behavior and characteristics in the area, the potential for mass movements in the area can be detected early, anticipation can be made, and countermeasures can be planned in the framework of designing a landslide disaster mitigation model.

\section{CONCLUSIONS}

Based on the results of the study, the following conclusions can be drawn:

The geomorphology of the research area consists of homoclinic hills, undulating wavy plains, and denudated volcanic hills. The lithology of the study area comprises sandstone units of the Halang Formation, from the late Miocene, and andesite breccia of the Peniron Formation, from the Pliocene epoch, with conformable stratigraphic relationships. There is a normal left slip fault, called the Blimbing Fault, striking $\mathrm{N}^{\circ} \mathrm{E}$ and dipping $70^{\circ}$.

Slope 1 (LR1) and Slope 5 (LR5) are composed of high-plastic clay with very expansive properties. Slope 2 (LR2) is a high-plastic silt with non-extensive properties. Slope 3 (LR3), Slope 4 (LR4), Slope 6 (LR6), and Slope 7 (LR7) are high-plastic silt with slightly expansive to very expansive properties. Using the simplified Bishop method, the safety factor of slopes composed of soil (LR1 to LR7) is $1.095,1.369,1.262,1.128,1.605,1.570$, and 0.961 , respectively, with slump or landslide type of movement. Slope 8 (LR8) has many discontinuities with a joint density of $0.36 \mathrm{~m}$. The RMR value is 38 , which belongs to rock mass class IV, or poor rock. The potential for movement is in the form of wedges and toppling types.

The effect of soil water content is to increase the load of the slopes by $15 \%$, decreasing the cohesion value (c), and reducing the friction angle $(\square)$. The friction angle decreases when the water content is more than $70 \%$. The types of soil are high-plastic clay and high-plastic silt with smactite mineral, slightly expansive to very expansive. The velocity of water movement on the slope is very low, making the slope more conducive for ground or mass movements to occur.

Factors influencing soil behavior in the occurrence of mass movement are the type of clay mineral (smactite group) and the amount of water content in the soil. This study indicates that information on soil behavior and characteristics is important to stakeholders for landslide-prone area management, especially for anticipating and countermeasure planning in the framework of landslide disaster mitigation. 


\section{ACKNOWLEDGEMENT}

This study was held with the support of the Geological Engineering Department of Universitas Pembangunan Nasional Veteran Yogyakarta. In relation to that, the authors express their high appreciation and deep gratitude to the institution for its backing in the operation of this study.

\section{R E F E R E N C E S}

Bieniawski, Z. T. (1989). Engineering rock mass classifications: a complete manual for engineers and geologists in mining, civil, and petroleum engineering. Wiley-Interscience.

BMKG (Badan Meteorologi Klimatologi dan Geofisika), (2021). Peta distribusi curah hujan bulan Januari 2021 Jawa Tengah. Semarang: [online] (http://iklimjateng.info/index.php/informasi-iklim/informasiiklim-2/informasi-iklim-5).

BPS (Badan Pusat Statistik), (2020). Jumlah Kejadian Bencana Alam Menurut Kabupaten/Kota di Provinsi Jawa Tengah. Jawa Tengah: [online] (https://jateng.bps.go.id/indicator/152/511/1/jumlah-kejadian-bencanaalam-menurut-kabupaten-kota-di-provinsi-jawa-tengah.html).

Citrabhuwana, B.N.K., Kusumayudha S.B., and Purwanto, (2016). Geology and slope stability analysis using markland method on road segment of Piyungan-Patuk, Sleman, Gunungkidul Regencies, Yogyakarta Special Region, Indonesia, International Journal of Economic and Environmental Geology, vol. 7, no. 1, pp 16-21, www.econ-environ-geol.org.

Duncan, C. I., and Fasce, J. (1992). Soil and Foundations For Architects and Engineers. (E. M. Walters, Ed) (Second Edition). Texas: Springer Science+Business Media, LLC, pp, 23-32.

Hardiyatmo, H. C. (2014). Mekenika Tanah 1 (Ke Tujuh). Yogyakarta: Gadjah Mada Universiry Press, pp, 3, $39,48,51,329$.

Hoek, E., and Bray, J. (1997). Rock Slope Enginering (Revised Second Edition). London: Intitution Of Mining and Metallurgy, pp, 150, 182.

Imam, A. N., (2021). Tanah Bergerak di Bruno, 2 rumah roboh, belasan lainnya terancam longsor. Purworejonews.com. [online] (http://purworejonews.com/tanah-bergerak-di-bruno-2-rumah-robohbelasan-lainnya-terancam-longsor/).

Kusumayudha, S. B., and Ciptahening, A. N. (2016). Correlation Between Tectonic Evironment and Characteristics of Mass Movement (Landslides): A Case Study From Java, Indonesia. The Jurnal of Geology Resource and Engineering. 4(2). 1-17, www.davidpublisher.com), http://eprints.upnyk.ac.id/id/eprint/9028

Kusumayudha, S.B., Ciptahening, A.N., Purwanto, H.S., Kristanto, W.A.D, Nugroho, N.E. (2020). Slope Movement Characteristic and Models based on Engineering-geological Properties of the Menoreh Hills, Purworejo Regency, Central Java, Indonesia, AIP Conference Proceedings 2245, 070014 (2020); https://doi.org/10.1063/5.0010201

Nelson, J. D., and Miller, D. J. (1991). Expansif Soils. Colorado: John Wiley \& Sons, Inc, p, 12.

Rajagukguk, O.C.P., Tarigan, A.E., dan Monintja, S. 2014. Analisis Kestabilan Lereng Dengan Metode Fillenius (Studi Kasus: Kawasan Citraland sta. 1000 m). Jurnal Sipil Statik, 2(3). 140-147.

Van Bemmelen, R. W. (1949). The Geology of Indonesia (Vol. IA). Netherlands: Government Printing Office, $\mathrm{p}, 26$.

Van Zuidam, R. A. (1984). Guide To Geomorphologic Aerial Photographic Interpretation And Mapping. Enschede the Netherlands: ITC, p, 43.

Varnes, D. J. (1978). Slope Movement Type and Processes, Special Report 176; Lindslide; Analisis and Control (Schuster, R.L. and Krizek, R.J.), Washingron, D.C: Transport Research Board, National Research Council, p, 11.

Wicaksono, B. A. (2020). Purworejo Masuk Wilayah Risiko Rawan Bencana di Jateng. M.medcom.id. [Online] (https://m.medcom.id/nasional/daerah/3NOqy83k-purworejo-masuk-wilayah-risiko-rawan-bencana-dijateng). 